NASA/TM-2002-211688

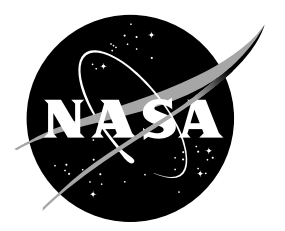

\title{
Influence of Cooling Hole Geometry and Material Conductivity on the Thermal Response of Cooled Silicon Nitride Plate
}

\author{
Ali Abdul-Aziz \\ Cleveland State University, Cleveland, Ohio \\ Ramakrishna T. Bhatt \\ U.S. Army Research Laboratory, Glenn Research Center, Cleveland, Ohio \\ Morris Girgis \\ Central State University, Wilberforce, Ohio
}


Since its founding, NASA has been dedicated to the advancement of aeronautics and space science. The NASA Scientific and Technical Information (STI) Program Office plays a key part in helping NASA maintain this important role.

The NASA STI Program Office is operated by Langley Research Center, the Lead Center for NASA's scientific and technical information. The NASA STI Program Office provides access to the NASA STI Database, the largest collection of aeronautical and space science STI in the world. The Program Office is also NASA's institutional mechanism for disseminating the results of its research and development activities. These results are published by NASA in the NASA STI Report Series, which includes the following report types:

- $\quad$ TECHNICAL PUBLICATION. Reports of completed research or a major significant phase of research that present the results of NASA programs and include extensive data or theoretical analysis. Includes compilations of significant scientific and technical data and information deemed to be of continuing reference value. NASA's counterpart of peerreviewed formal professional papers but has less stringent limitations on manuscript length and extent of graphic presentations.

- TECHNICAL MEMORANDUM. Scientific and technical findings that are preliminary or of specialized interest, e.g., quick release reports, working papers, and bibliographies that contain minimal annotation. Does not contain extensive analysis.

- CONTRACTOR REPORT. Scientific and technical findings by NASA-sponsored contractors and grantees.
- CONFERENCE PUBLICATION. Collected papers from scientific and technical conferences, symposia, seminars, or other meetings sponsored or cosponsored by NASA.

- SPECIAL PUBLICATION. Scientific, technical, or historical information from NASA programs, projects, and missions, often concerned with subjects having substantial public interest.

- TECHNICAL TRANSLATION. Englishlanguage translations of foreign scientific and technical material pertinent to NASA's mission.

Specialized services that complement the STI Program Office's diverse offerings include creating custom thesauri, building customized databases, organizing and publishing research results ... even providing videos.

For more information about the NASA STI Program Office, see the following:

- Access the NASA STI Program Home Page at http://www.sti.nasa.gov

- E-mail your question via the Internet to help@sti.nasa.gov

- Fax your question to the NASA Access Help Desk at 301-621-0134

- Telephone the NASA Access Help Desk at 301-621-0390

- Write to:

NASA Access Help Desk

NASA Center for AeroSpace Information 7121 Standard Drive

Hanover, MD 21076 
NASA/TM-2002-211688

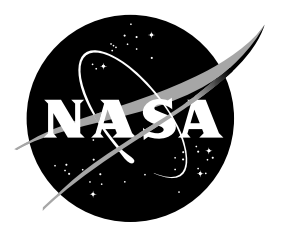

\title{
Influence of Cooling Hole Geometry and Material Conductivity on the Thermal Response of Cooled Silicon Nitride Plate
}

\author{
Ali Abdul-Aziz \\ Cleveland State University, Cleveland, Ohio \\ Ramakrishna T. Bhatt \\ U.S. Army Research Laboratory, Glenn Research Center, Cleveland, Ohio \\ Morris Girgis \\ Central State University, Wilberforce, Ohio \\ Prepared for the \\ 26th Annual International Conference on Advanced Ceramics and Composites \\ sponsored by the American Ceramic Society \\ Cocoa Beach, Florida, January 13-18, 2002
}

National Aeronautics and

Space Administration

Glenn Research Center 
This report is a formal draft or working paper, intended to solicit comments and ideas from a technical peer group.

This report contains preliminary findings, subject to revision as analysis proceeds.

The Aerospace Propulsion and Power Program at NASA Glenn Research Center sponsored this work.

Available from

NASA Center for Aerospace Information 7121 Standard Drive

Hanover, MD 21076
National Technical Information Service 5285 Port Royal Road Springfield, VA 22100

Available electronically at http:/ /gltrs.grc.nasa.gov 


\title{
Influence of Cooling Hole Geometry and Material Conductivity on the Thermal Response of Cooled Silicon Nitride Plate
}

\author{
Ali Abdul-Aziz ${ }^{1}$ \\ Department of Civil and Environmental Engineering \\ Cleveland State University \\ Cleveland, Ohio 44115 \\ Ramakrishna T. Bhatt ${ }^{2}$ \\ U.S. Army Research Laboratory \\ National Aeronautics and Space Administration \\ Glenn Research Center \\ Cleveland, Ohio 44135 \\ Morris Girgis ${ }^{3}$ \\ Department of Manufacturing Engineering \\ Central State University \\ Wilberforce, Ohio 45384
}

\begin{abstract}
Summary
To complement the effectiveness of ceramic materials and their applicability to turbine engine applications, a parametric study using the finite element method was carried out. This study conducted thorough analyses of a thermal-barrier-coated silicon nitride $\left(\mathrm{Si}_{3} \mathrm{~N}_{4}\right)$ plate specimen with cooling channels, where its thermal conductivity was varied in an attempt to minimize the thermal stresses and reach an optimal state of stress. The thermal stress profile was generated for specimens with circular and square cooling channels. Lower stresses were reported for a higher magnitude of thermal conductivity and in particular for the circular cooling channel arrangement. Contour plots for the stresses and the temperature are presented and results obtained are discussed.
\end{abstract}

\section{Introduction}

Lightweight, strong, tough high-temperature materials are required to complement efficiency improvements for next-generation gas turbine engines that can operate with minimum cooling. Because of their low density, high-temperature strength, and thermal conductivity, ceramic matrix composites are being investigated as potential materials for replacing nickel-base superalloys currently used for hot-section engine components.

Ceramic structures can withstand higher operating temperatures and harsh combustion environments. In addition, their low densities relative to metals help to reduce component mass (refs. 1 and 2) and hence the engine weight and ultimately the fuel consumption.

\footnotetext{
${ }^{1}$ NASA Resident Research Associate at Glenn Research Center, Telephone: 216-433-6729, Fax: 216-977-7150, E-mail: smaziz@grc.nasa.gov.

${ }^{2}$ Telephone: 216-433-5513, Fax: 216-433-5544, E-mail: bhatt@grc.nasa.gov.

${ }^{3}$ Telephone: 937-376-6309, Fax: 937-376-6679, E-mail: mgirgis@ @su.ces.edu.
} 
The general objectives of this research are to develop the manufacturing technology, the thermal and environmental barrier coating (TBC/EBC) system, and the analytical modeling capability to predict the thermomechanical stresses for testing minimally cooled silicon nitride burner rig specimens under simulated engine conditions. These stresses, resulting from the high temperatures in turbine engine environments, may affect the durability of engine components. To minimize the thermal stress, this report analyzes the effects of thermal conductivity (which varies with the temperature changes in these environments) and cooling channel geometry on the temperature distribution for coated silicon nitride in a burner rig environment.

\section{Analytical Approach}

Two-dimensional finite element analyses were performed in a parametric study in which heat transfer and stress analyses were conducted under steady-state conditions to demonstrate the feasibility of using cooled $\mathrm{Si}_{3} \mathrm{~N}_{4}$ parts for turbine engine applications. The calculations were made under linear elastic conditions where the behavior of the material was defined by two material constants, Young's modulus and Poisson's ratio. The geometry of a silicon nitride plate with cooling channels used for the finite element analysis is shown in figure 1. Plate-shaped specimens were used in these analyses to simulate conditions and environmental behavior typically experienced by vanes in turbine engines. The test specimens consist of a square silicon nitride substrate with four coating layers arranged in the following order: a top layer of mullite, a second layer of combined mullite and $20 \mathrm{wt} \%$ barium strontium aluminosilicate (BSAS), a third layer of BSAS, and a fourth layer of zirconia. The first three layers each have an equal thickness of $0.0765 \mathrm{~mm}$, and the zirconia layer has a thickness of $0.0254 \mathrm{~mm}$. Figure 1 shows the test specimen with eight 2.03 -mm-diameter cylindrical cooling channels spaced $1.02 \mathrm{~mm}$ apart. The specimen with the square cooling channels has edge dimensions equal to the diameter of the cylindrical channels in this specimen.

The analyses embraced a thermal model that closely simulated impingement heating applied on the plate by a burner rig flame generated during previous experiments (Dennis Fox, 2001, NASA Glenn Research Center, experimental work). The hot flame was pointed symmetrically at the center region with the gas temperature being linearly dissipated over the rest of the plate. Because of symmetry, only half the plate was modeled. The steady-state temperature distributions were generated. All the finite element calculations were conducted with ANSYS 5.7 code (ref. 3).

\section{Finite Element Analysis}

\section{Mesh Generation}

Stress and steady-state heat transfer analyses were conducted to simulate a burner rig experimental setup that included internal cooling by air. The finite element model was generated with MSC/PATRAN graphics (ref. 4). Figures 2 and 3 represent the twodimensional finite element models for the square and the circular channel test specimen configurations, respectively. The models consist of 10216 eight-node quad elements and 31475 nodes for the circular-channeled specimens and 9740 eight-node quad elements and 30145 nodes for the square-channeled specimens. The specimen was constrained along the line of symmetry by restraining all the nodes from moving along 
the X-direction, and another node was constrained along the Y-direction to suppress rigid body motion (see fig. 3 ).

\section{Heat Transfer Analysis}

The thermal boundary conditions applied were fundamental in evaluating the thermal profile predicted by the analyses. Several assumptions were made to model the heat transfer phenomena experienced by the test specimen. Furthermore, convective boundary conditions were applied, and the corresponding heat transfer coefficients were obtained from reference 5. Convective flame impingement was imposed over the top of the plate, while convective cooling was applied to the bottom of the plate and inside the cooling channels, as shown in figure 2. Also note in figure 2 that the convective heat transfer coefficient was linearly varied from the center to the edge, simulating a decaying flame. At the center, impingement heating conditions were imposed, and the forced-convection state between the flame and the plate surface had a convective coefficient value of $883 \mathrm{~W} / \mathrm{m}^{2}{ }^{\circ} \mathrm{C}$ associated with a gas temperature of $1982{ }^{\circ} \mathrm{C}$. This value of heat transfer coefficient corresponds well with values of heat transfer coefficients for superheated steam or air under forced convection (ref. 5), which are highly representative of data used for an impingement heating environment. At the edge, a convective heat transfer coefficient of $6 \mathrm{~W} / \mathrm{m}^{2}{ }^{\circ} \mathrm{C}$ was applied, representing the free-convection state considered in the analysis. The gas temperature was linearly tapered off across the plate from a high of $1982{ }^{\circ} \mathrm{C}$ until it reached a low of $700{ }^{\circ} \mathrm{C}$.

The cooling channels and the specimen bottom were modeled with a convective heat transfer coefficient of $114 \mathrm{~W} / \mathrm{m}^{2}{ }^{\circ} \mathrm{C}$, a typical value for water cooling in a forcedconvection state (ref. 5) and a gas temperature of $700{ }^{\circ} \mathrm{C}$. Air is the cooling medium assumed in these analyses.

A symmetry boundary condition was imposed at the specimen midregion because only half the specimen was considered for the analyses. All the coating layers were included in the analyses; layers of elements representing the coatings in the order described in figure 1 were generated. More details pertaining to the thermal modeling can be found in reference 1 . The material properties for the coatings and the silicon nitride are listed in table I.

\section{Discussion of Results}

Contour plots showing the silicon nitride thermal and structural response are shown in figures 4 to 7 . The temperature and the axial stress as a function of the thermal conductivity for the circular and square cooling channel configurations are also shown in figures 8 and 9 . The temperature and the stress results presented were generated under cooling conditions.

Figures 4 and 5 represent the contour plots of the temperature distribution at a silicon nitride thermal conductivity of $100 \mathrm{~W} / \mathrm{m}{ }^{\circ} \mathrm{C}$. They indicate that the maximum temperature is at the center section of the plate as expected. Additionally, the influence of the cooling channel configuration is clearly exhibited by the temperature distribution between the two channel layouts. A hotter region is recognized for the square configuration. Figures 4 and 5 show the silicon nitride temperature predicted by the analysis. Furthermore, temperature effects of the material properties reported in Table I 
were all incorporated into the analyses. Such implementation has enabled accounting for all the thermal conductivity variations due to material properties changes with temperature. Figures 6 and 7 illustrate the axial stresses as a result of the thermal loading conditions applied. Similar stress distribution trends for both cooling channel shapes are clearly indicated. However, the stresses were lower, close to 50 percent, for the circular cooling channel plate compared with that of the square channels. High stress concentrations are seen at the square corners and specifically near the flame area (see fig. 6). The plate with the circular cooling channels experienced high stresses at the top section of the channels along the $90^{\circ}$ angle (see fig. 7); however, no stress concentrations were noted. Thus, a circular cooling channel configuration seems to be more suitable for intended turbine engine applications.

The data presented in figures 8 and 9 show the effects of both the shape of the cooling channels and the thermal conductivity simultaneously. For instance, figure 8 illustrates the variation of the temperature under cooling conditions as the thermal conductivity of the silicon nitride is increased from 2 to $100 \mathrm{~W} / \mathrm{m}{ }^{\circ} \mathrm{C}$. This variation range was randomly chosen in an attempt to evaluate a broader spectrum of material conductivity data. It is obvious that the temperature is decreased as the thermal conductivity increases. Note also that the specimens with the square and the circular cooling channels were at nearly the same temperature over the conductivity range considered. This is attributed to the similarity in the boundary conditions applied.

In figure 9 the maximum axial stress of the silicon nitride as a function of the thermal conductivity decreases as the thermal conductivity increases. Furthermore, the reduction of the stresses relative to the change in the thermal conductivity magnitude as it varied from 2 to $100 \mathrm{~W} / \mathrm{m}^{\circ} \mathrm{C}$ is about 18 percent. This leads to the conclusion that at higher thermal conductivity the stresses become lower. However, the extent to which this decrease in stress, resulting from the thermal conductivity variation, affects the material's durability may be difficult to predict. Other factors like the coating materials and the thermal boundary conditions may have contributed to the outcome of these analyses and affected the conductivity influence of the ceramic on the stress response.

\section{Conclusions}

A parametric study using the finite element method was conducted to investigate the effects of varying the thermal conductivity and the cooling channel geometry on the thermomechanical response of a prototype coated silicon nitride $\left(\mathrm{Si}_{3} \mathrm{~N}_{4}\right)$ cooling-plate panel specimen. The analyses showed a decrease of about 18 percent in the stresses of the silicon nitride when the thermal conductivity was increased from 2 to $100 \mathrm{~W} / \mathrm{m}{ }^{\circ} \mathrm{C}$. The plate specimen with circular cooling channels showed no stress concentration; in comparison, the specimen with the square cooling channels experienced stress risers at the channel corners. Layers of coating, as well as other factors such as boundary conditions, may have affected the changes reported as resulting from thermal conductivity variations. The current study offers a preliminary baseline assessment of the effects of the thermal conductivity on the thermomechanical response of the silicon nitride; however, more work is warranted under more realistic boundary conditions to reach a more conclusive statement relative to gains and benefits achieved with respect to durability. Efforts are in progress to study the effects of other key parameters such as material surface roughness, the thermal and environmental barrier coating (TBC/EBC) system, and the coolant pressure differential as expressed with more representative thermal boundary conditions. 


\section{References}

1. Abdul-Aziz, Ali; Baaklini, George Y.; and Bhatt, Ramakrishna T.: Design Evaluation Using Finite Element Analysis of Cooled Silicon Nitride Plates for a Turbine Blade Application. NASA/TM2001-210819. http://gltrs.grc.nasa.gov/ Accessed June 17, 2001.

2. Bhatt, Ramakrishna T.: Minimally Cooled Ceramics and Fiber Reinforced Ceramic Matrix Composite Turbine Components-A Progress Report. NASA/CP-1999-208915, vol. 2, 1999. Available from the NASA Center for Aerospace Information.

3. ANSYS 5.7 computer program, ANSYS, Inc., Canonsburg, PA, 2000.

4. MSC-Patran MSC-Nastran Preference Guide. Vols. 1 and 2, MacNeal-Schwendler Corporation, Santa Ana, CA, 1997.

5. Wolf, Helmut: Heat Transfer. Harper \& Row, New York, NY, 1983.

6. Engineering Property Data on Selected Ceramics. Metals and Ceramics Information Center Report MCIC-HB-07, vol. 1, 1976.

7. Richerson, David W.: Modern Ceramic Engineering. Marcel Dekker, Inc., New York, NY, 1982.

8. Engineering Property Data on Selected Ceramics. Metals and Ceramics Information Center Report MCIC-HB-07, vol. 3, 1981.

TABLE I.-MECHANICAL AND THERMAL PROPERTIES OF MATERIALS

\begin{tabular}{|c|c|c|c|c|c|}
\hline Material & $\begin{array}{c}\text { Temperature, } \\
{ }^{\circ} \mathrm{C}\end{array}$ & $\begin{array}{c}\text { Elastic } \\
\text { modulus, } \\
\text { GPa }\end{array}$ & $\begin{array}{l}\text { Poisson's } \\
\text { ratio }\end{array}$ & $\begin{array}{c}\text { Coefficient of thermal } \\
\text { expansion, } \\
10^{-6} /{ }^{\circ} \mathrm{C}\end{array}$ & $\begin{array}{l}\text { Thermal } \\
\text { conductivity, } \\
\mathrm{W} / \mathrm{m}^{\circ} \mathrm{C}\end{array}$ \\
\hline Silicon nitride $^{\mathrm{a}}$ & $\begin{array}{c}25 \\
1386\end{array}$ & $\begin{array}{l}300 \\
250\end{array}$ & $\begin{array}{r}0.22 \\
.19\end{array}$ & $\begin{array}{l}8.380 \\
8.380\end{array}$ & $\begin{array}{l}30.0 \\
12.0\end{array}$ \\
\hline BSAS $^{\mathrm{a}, \mathrm{b}}$ & $\begin{array}{c}25 \\
1386 \\
\end{array}$ & $\begin{array}{l}95 \\
95 \\
\end{array}$ & $\begin{array}{l}---- \\
---- \\
\end{array}$ & $\begin{array}{l}23.96 \\
23.96\end{array}$ & $\begin{array}{c}2.0 \\
.50 \\
\end{array}$ \\
\hline Mullite $^{\mathrm{c}}$ & $\begin{array}{c}25 \\
1386\end{array}$ & $\begin{array}{l}145 \\
145\end{array}$ & $\begin{array}{l}.20 \\
.20\end{array}$ & $\begin{array}{l}13.46 \\
13.46\end{array}$ & $\begin{array}{l}5.86 \\
3.87\end{array}$ \\
\hline $\begin{array}{l}\text { BSAS-mullite } \\
\text { mixture }^{\mathrm{a}}\end{array}$ & $\begin{array}{c}25 \\
1386\end{array}$ & $\begin{array}{l}120 \\
120\end{array}$ & ---- & $\begin{array}{l}18.71 \\
18.71\end{array}$ & $\begin{array}{l}2.0 \\
.24\end{array}$ \\
\hline Porous zirconia ${ }^{\mathrm{d}}$ & $\begin{array}{c}25 \\
1386\end{array}$ & $\begin{array}{l}0.0025 \\
0.0025\end{array}$ & $\begin{array}{l}.25 \\
.25\end{array}$ & $\begin{array}{l}28.75 \\
28.75\end{array}$ & $\begin{array}{l}2.0 \\
.50\end{array}$ \\
\hline
\end{tabular}

${ }^{\mathrm{a}}$ Ref. 6.

${ }^{\mathrm{b}} \mathrm{BSAS}$ is barium strontium aluminosilicate.

${ }^{\mathrm{c}}$ Ref. 7.

${ }^{\mathrm{d}}$ Ref. 8. 
Coating layers: Mullite, mullite-BSAS,

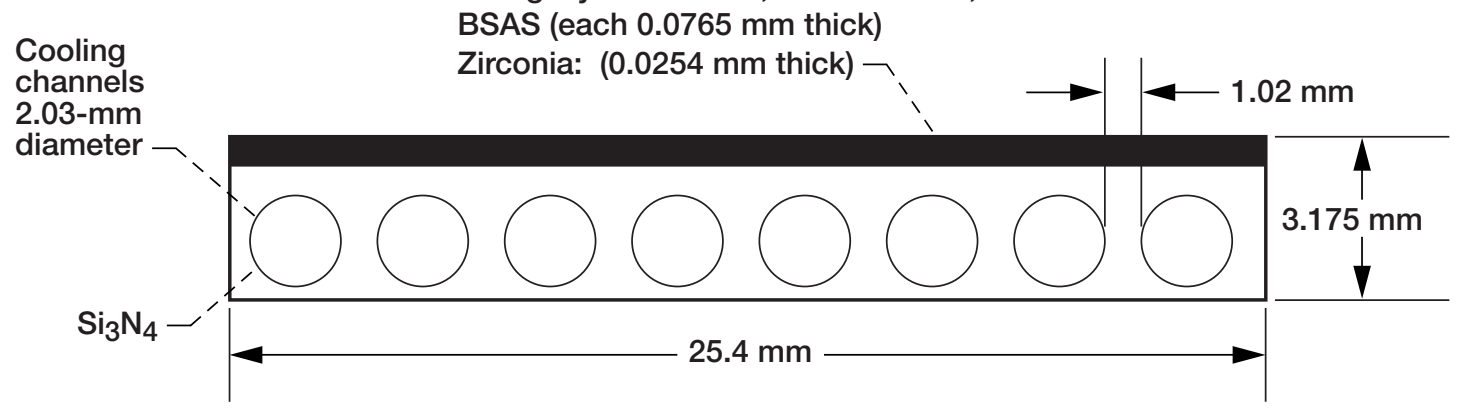

Figure 1.-Monolithic silicon nitride $\left(\mathrm{Si}_{3} \mathrm{~N}_{4}\right)$ circular-channeled cooling panel cross section. BSAS is barium strontium aluminosilicate.

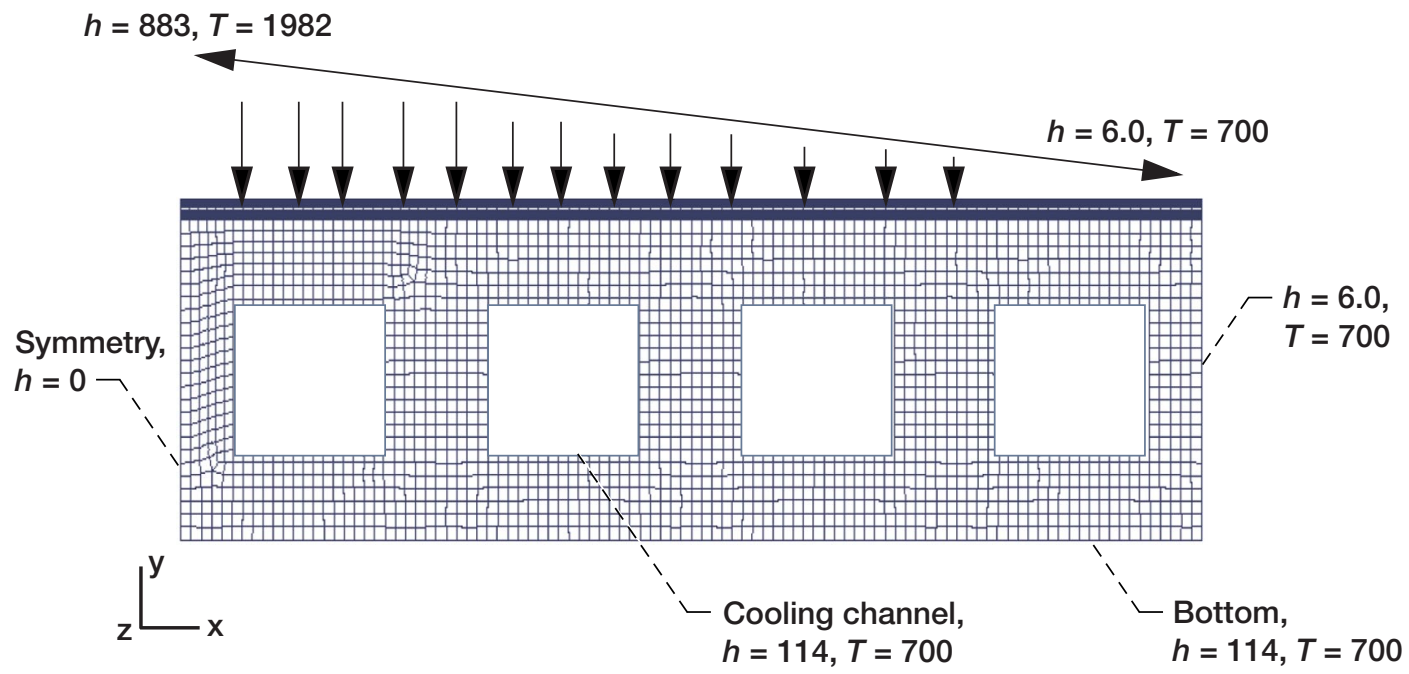

Figure 2.-Two-dimensional finite element model of square configuration (9740 eight-node quad elements, 30145 nodes) and thermal boundary conditions showing applied gas temperature, $T\left({ }^{\circ} \mathrm{C}\right)$ and heat transfer coefficients, $h\left(\mathrm{~W} / \mathrm{m}^{2}{ }^{\circ} \mathrm{C}\right)$.

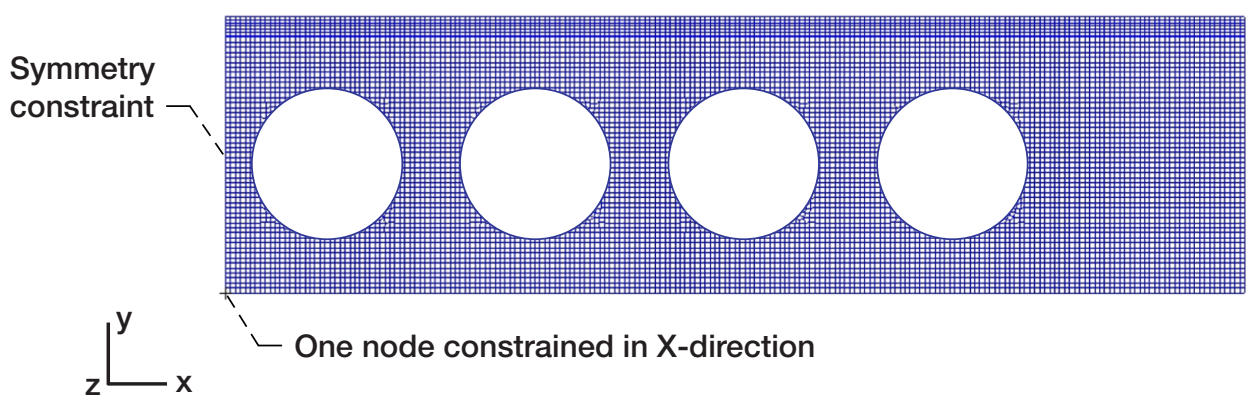

Figure 3.-Circular configuration finite element model (10 216 eight-node quad elements, 31475 nodes) and boundary conditions applied. 


Temperature,
${ }^{\circ} \mathrm{C}$
1149
1140
1132
1124
1116
1107
1099
1090
1082
1074
1065
1057
1049
1040
1032
1024

Figure 4.-Temperature distribution at thermal conductivity of $100 \mathrm{~W} / \mathrm{m}{ }^{\circ} \mathrm{C}$ for cooling with square channels.
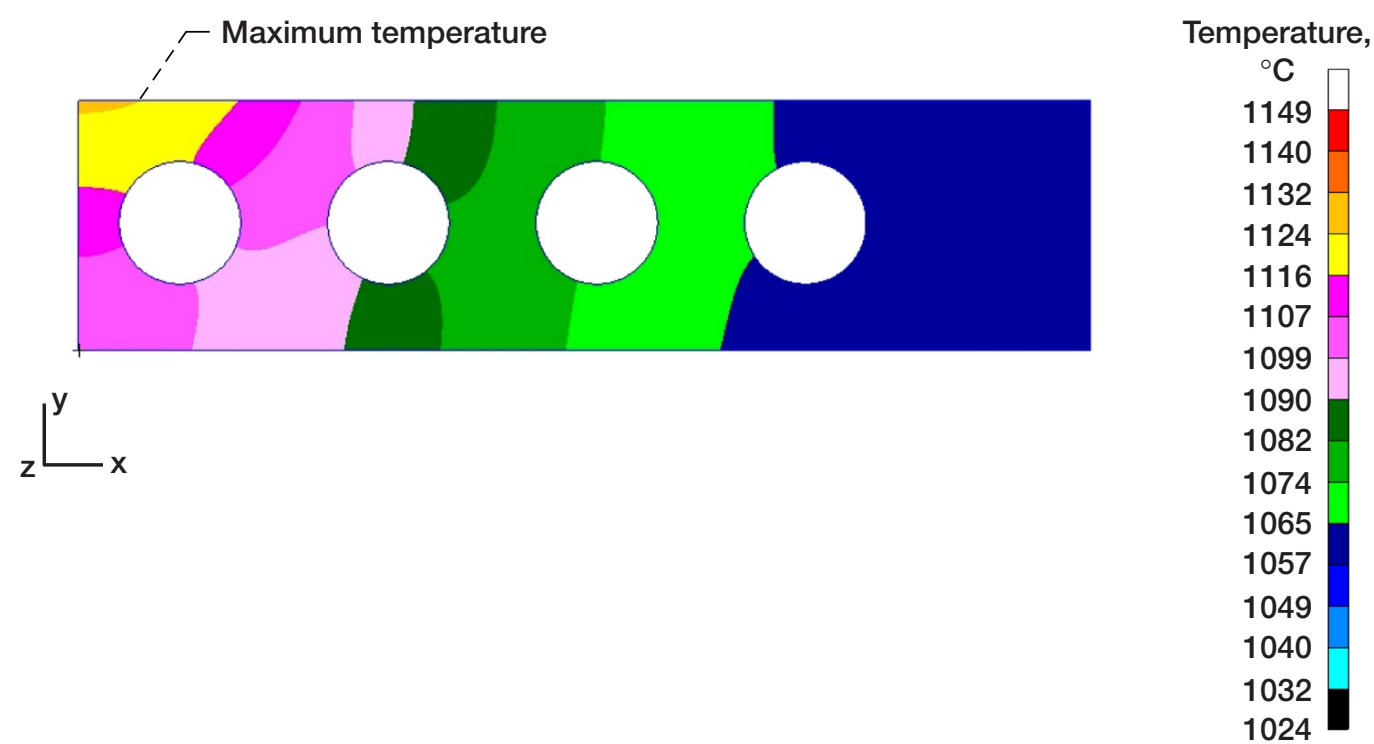

Figure 5.-Temperature distribution at thermal conductivity of $100 \mathrm{~W} / \mathrm{m}{ }^{\circ} \mathrm{C}$ for cooling with circular channels. 


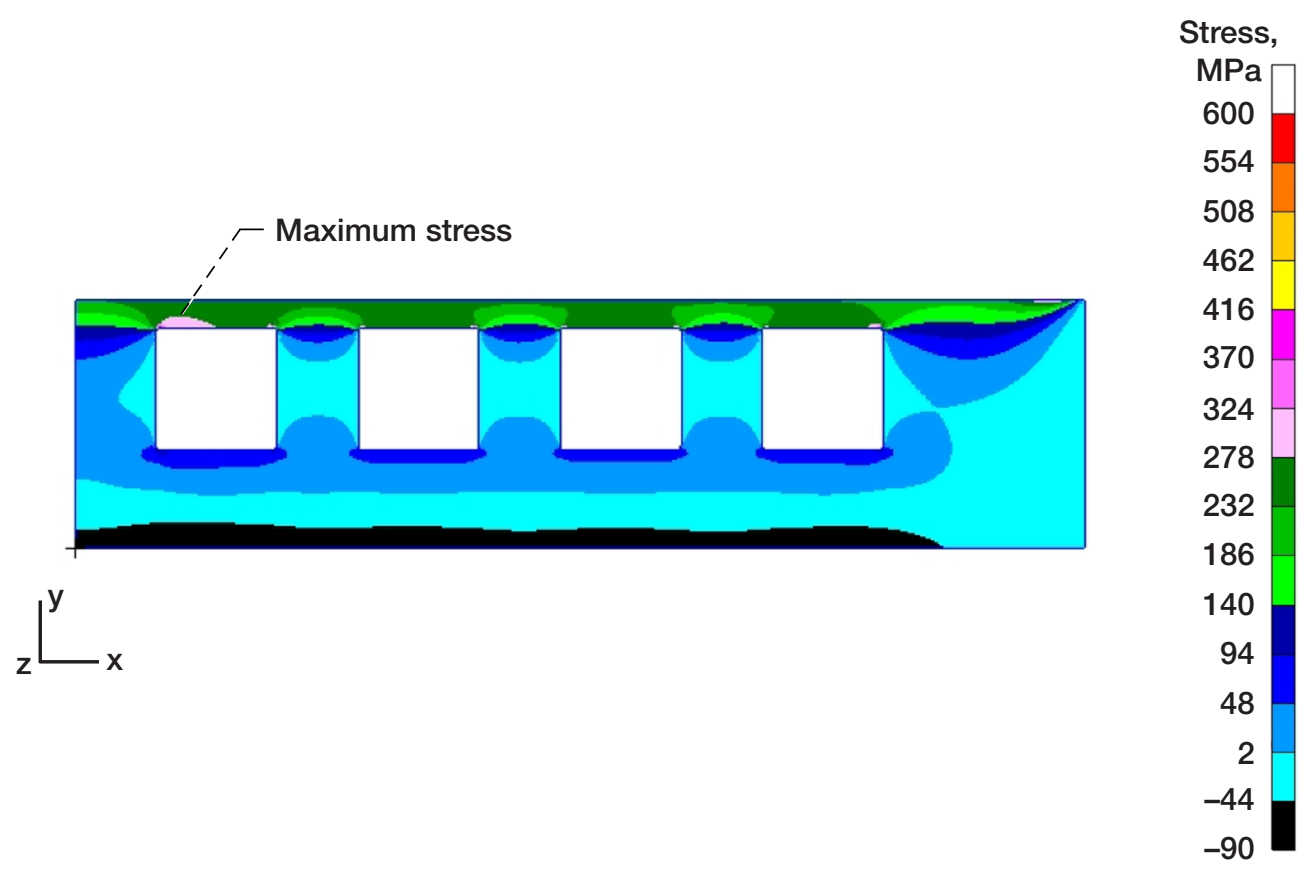

Figure 6.-Axial stress distribution at thermal conductivity of $100 \mathrm{~W} / \mathrm{m}{ }^{\circ} \mathrm{C}$ for cooling with square channels.

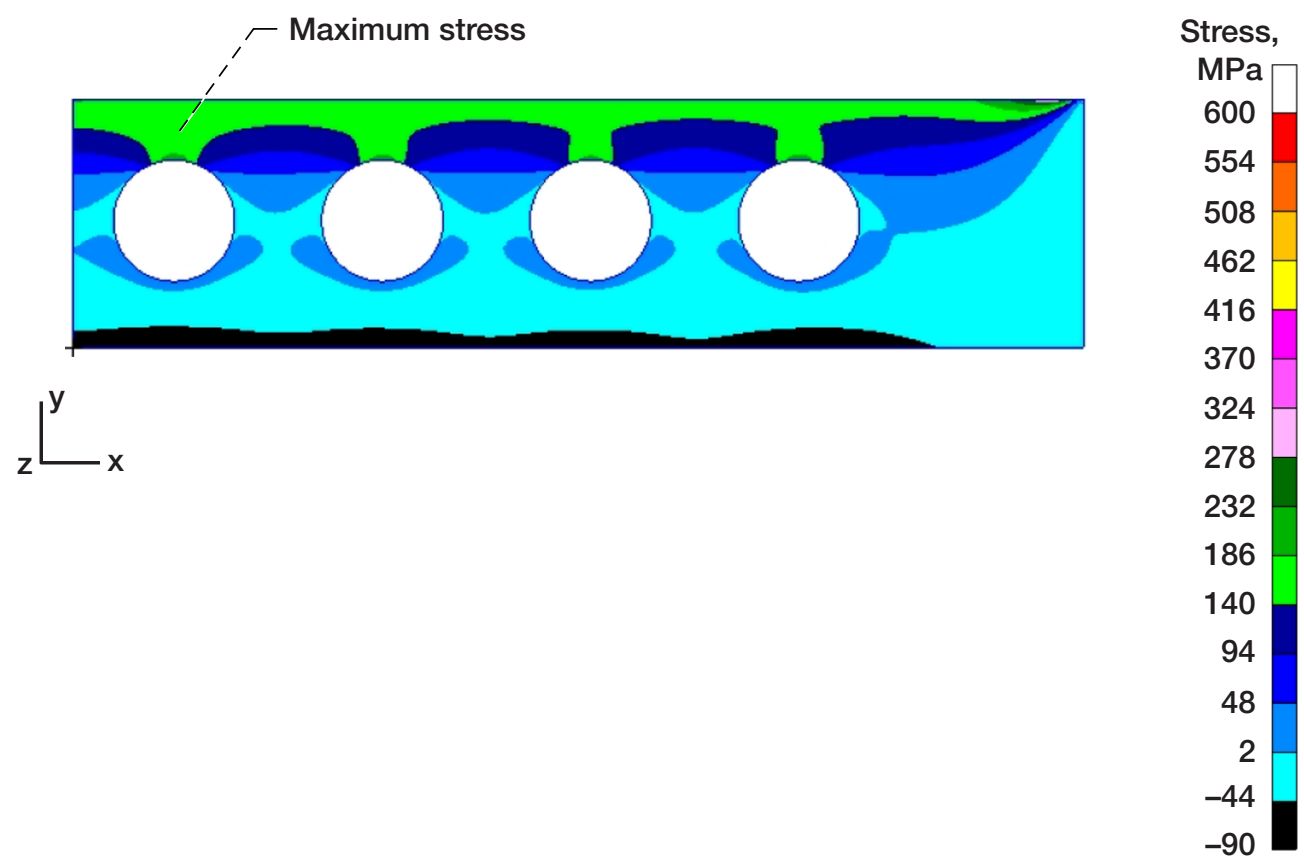

Figure 7.-Axial stress distribution at thermal conductivity of $100 \mathrm{~W} / \mathrm{m}{ }^{\circ} \mathrm{C}$ for cooling with circular channels. 


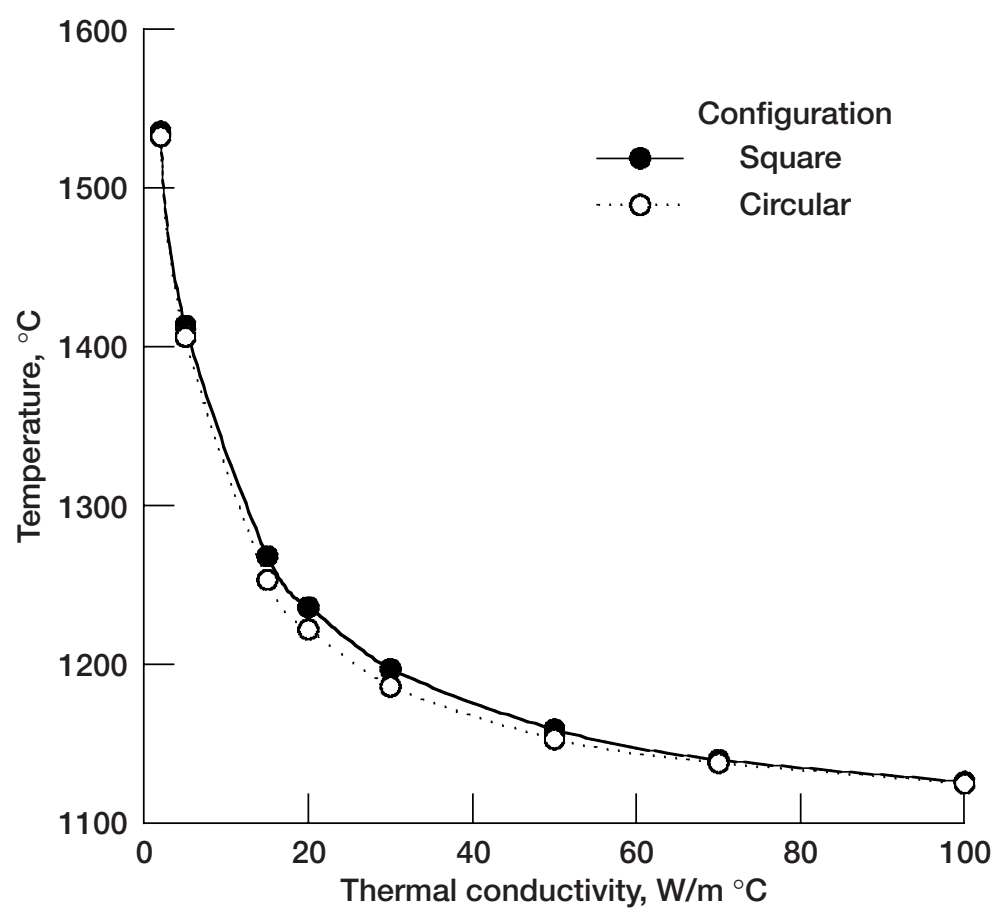

Figure 8.-Temperature of silicon nitride as function of thermal conductivity for two different cooling channel configurations.

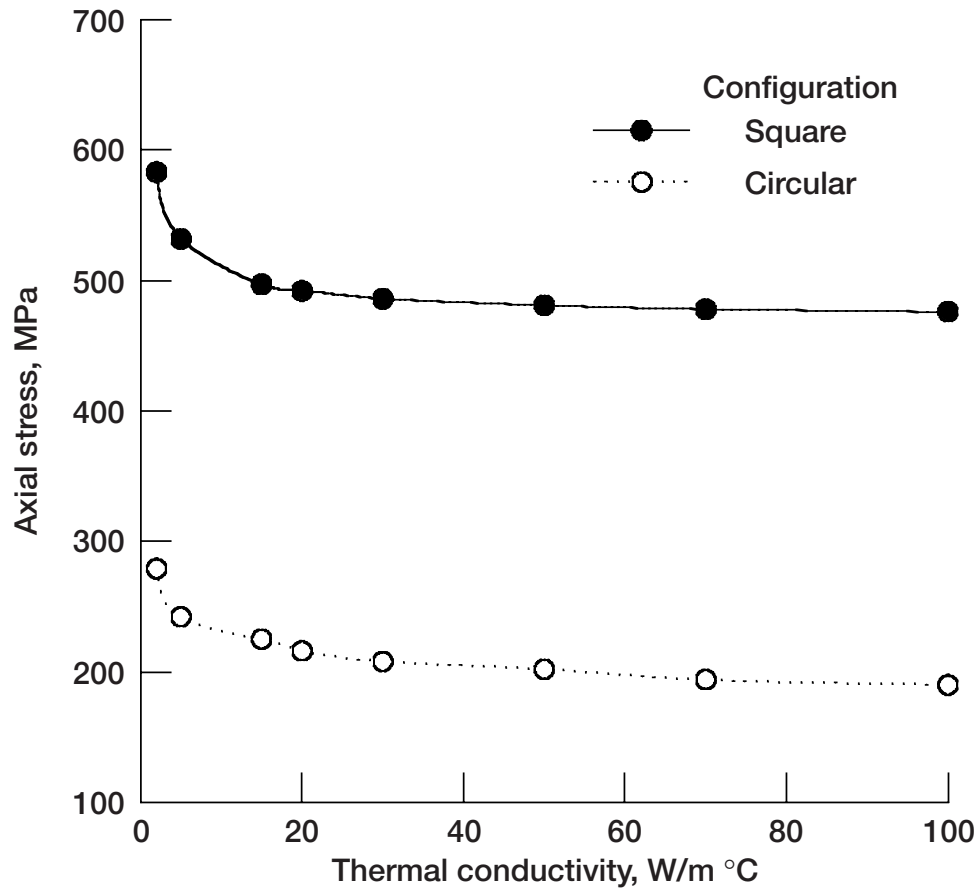

Figure 9.-Axial stress for silicon nitride in X-direction as function of thermal conductivity for two different cooling channel configurations. 
Public reporting burden for this collection of information is estimated to average 1 hour per response, including the time for reviewing instructions, searching existing data sources, gathering and maintaining the data needed, and completing and reviewing the collection of information. Send comments regarding this burden estimate or any other aspect of this collection of information, including suggestions for reducing this burden, to Washington Headquarters Services, Directorate for Information Operations and Reports, 1215 Jefferson Davis Highway, Suite 1204, Arlington, VA 22202-4302, and to the Office of Management and Budget, Paperwork Reduction Project (0704-0188), Washington, DC 20503.

\begin{tabular}{|l|l|l}
\hline 1. AGENCY USE ONLY (Leave blank) & $\begin{array}{c}\text { 2. REPORT DATE } \\
\text { November } 2002\end{array}$ & $\begin{array}{r}\text { 3. REPORT TYPE AND DATES COVERED } \\
\text { Technical Memorandum }\end{array}$ \\
\hline
\end{tabular}

4. TITLE AND SUBTITLE

5. FUNDING NUMBERS

Influence of Cooling Hole Geometry and Material Conductivity on the Thermal

Response of Cooled Silicon Nitride Plate

6. AUTHOR(S)

Ali Abdul-Aziz, Ramakrishna T. Bhatt, and Morris Girgis

WU-708-31-13-00

\section{PERFORMING ORGANIZATION NAME(S) AND ADDRESS(ES)}

8. PERFORMING ORGANIZATION

REPORT NUMBER

National Aeronautics and Space Administration

John H. Glenn Research Center at Lewis Field

Cleveland, Ohio 44135-3191

E-13417

\section{SPONSORING/MONITORING AGENCY NAME(S) AND ADDRESS(ES)}

National Aeronautics and Space Administration

Washington, DC 20546-0001

10. SPONSORING/MONITORING AGENCY REPORT NUMBER

NASA TM-2002-211688

\section{SUPPLEMENTARY NOTES}

Prepared for the 26th Annual International Conference on Advanced Ceramics and Composites sponsored by the American Ceramic Society, Cocoa Beach, Florida, January 13-18, 2002. Ali Abdul-Aziz, Cleveland State University, Cleveland, Ohio and NASA Resident Research Associate at Glenn Research Center; Ramakrishna T. Bhatt, U.S. Army Research Laboratory, NASA Glenn Research Center; Morris Girgis, Central State University, Wilberforce, Ohio 45384. Responsible person, Ali Abdul-Aziz, organization code 5920, 216-433-6729.

12a. DISTRIBUTION/AVAILABILITY STATEMENT

12b. DISTRIBUTION CODE

Unclassified - Unlimited

Subject Categories: 01 and 39

Distribution: Nonstandard

Available electronically at http://gltrs.grc.nasa.gov

This publication is available from the NASA Center for AeroSpace Information, 301-621-0390.

13. ABSTRACT (Maximum 200 words)

To complement the effectiveness of ceramic materials and their applicability to turbine engine applications, a parametric study using the finite element method was carried out. This study conducted thorough analyses of a thermal-barrier-coated silicon nitride $\left(\mathrm{Si}_{3} \mathrm{~N}_{4}\right)$ plate specimen with cooling channels, where its thermal conductivity was varied in an attempt to minimize the thermal stresses and reach an optimal state of stress. The thermal stress profile was generated for specimens with circular and square cooling channels. Lower stresses were reported for a higher magnitude of thermal conductivity and in particular for the circular cooling channel arrangement. Contour plots for the stresses and the temperature are presented and discussed.

\section{SUBJECT TERMS}

Ceramics; Finite elements; Cooling plates; Silicon nitride, Stress analysis; Cooling channels

17. SECURITY CLASSIFICATION OF REPORT

Unclassified
18. SECURITY CLASSIFICATION OF THIS PAGE

Unclassified
19. SECURITY CLASSIFICATION OF ABSTRACT

Unclassified
15. NUMBER OF PAGES

15

16. PRICE CODE

20. LIMITATION OF ABSTRACT

Standard Form 298 (Rev. 2-89)

Prescribed by ANSI Std. Z39-18 298-102 